This item was submitted to Loughborough's Research Repository by the author.

Items in Figshare are protected by copyright, with all rights reserved, unless otherwise indicated.

\title{
The recruitment of new teachers from minority ethnic groups
}

PLEASE CITE THE PUBLISHED VERSION

PUBLISHER

(c) Taylor and Francis

LICENCE

CC BY-NC-ND 4.0

\section{REPOSITORY RECORD}

Carrington, Bruce, Alistair Bonnett, Anoop Nayak, Christine Skelton, Fay Smith, Richard Tomlin, Geoffrey Short, and Jack Demaine. 2019. "The Recruitment of New Teachers from Minority Ethnic Groups". figshare. https://hdl.handle.net/2134/610. 
This item was submitted to Loughborough's Institutional Repository by the author and is made available under the following Creative Commons Licence conditions.

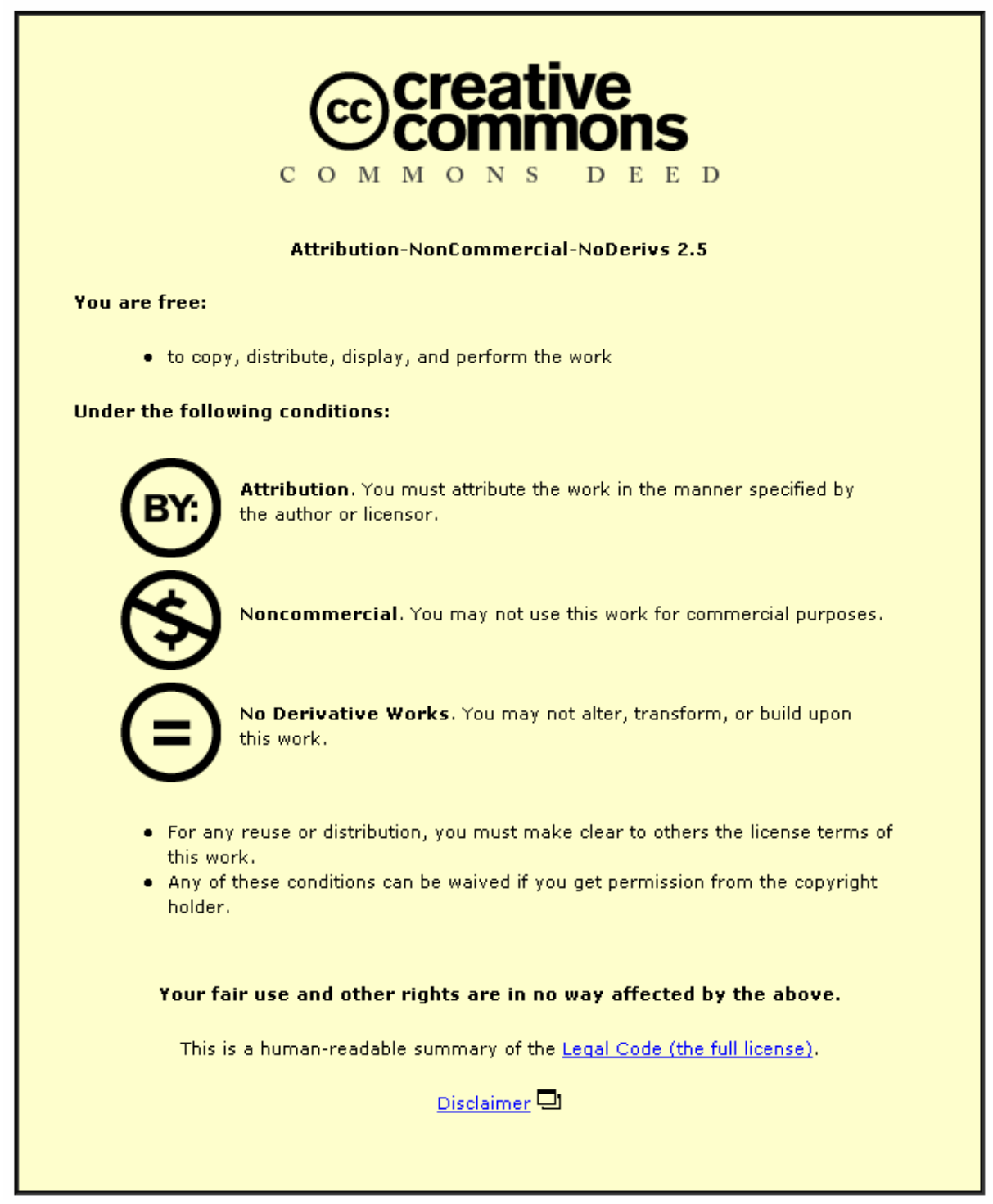

For the full text of this licence, please go to: http://creativecommons.org/licenses/by-nc-nd/2.5/ 


\title{
The Recruitment of New Teachers from Minority Ethnic Groups
}

\author{
BRUCE CARRINGTON, ALASTAIR BONNETT, \\ ANOOP NAYAK, CHRISTINE SKELTON, \\ FAY SMITH, RICHARD TOMLIN \\ University of Newcastle-upon-Tyne, United Kingdom \\ GEOFF SHORT \\ University of Hertfordshire, United Kingdom \\ JACK DEMAINE \\ Loughborough University, United Kingdom
}

\begin{abstract}
This article reports on part of a larger, ongoing two-year investigation supported by the Teacher Training Agency into the recruitment of new teachers from minority ethnic backgrounds via Postgraduate Certificate in Education (PGCE) courses in England. The authors focus here on interviews with admissions tutors, course directors and other senior staff at teacher training institutions. The interviews revealed differences between institutions in the measures taken to attract minority ethnic students. The research indicates a need for much clearer guidelines for admissions tutors on the issues surrounding the question of 'positive action' on the recruitment of new teachers from minority ethnic groups.
\end{abstract}

\section{Introduction}

Since the publication of the Rampton Report (1981) nearly 20 years ago, concern has been voiced about the under-representation of minority ethnic [1] groups in teaching in England and Wales, and their relative lack of opportunities for career advancement. The Commission for Racial Equality (CRE) has lobbied for policy interventions to address the issue and in the mid-1980s carried out a survey of staffing in eight local authorities that had 'higher than average' minority populations. This revealed that less than $3 \%$ of teachers came from minority ethnic backgrounds and also showed that such teachers were disproportionately concentrated on lower pay scales 
(Commission for Racial Equality, 1986, 1988). By 1992 the CRE was urging the Conservative Government to take appropriate steps 'to ensure that people from the ethnic minorities will be recruited for teacher training without unlawful discrimination' (cited in Osler, 1997, p. 47). Subsequently, the Higher Education Funding Council for England (HEFCE) responded by funding 17 projects to widen ethnic minority participation in initial teacher training between 1993 and 1994 (Higher Education Funding Council for England, 1995).

In October 1997 the Teacher Training Agency (TTA) and the CRE launched a series of regional conferences addressing the theme 'Teaching in Multi-ethnic Britain'. This initiative to boost minority recruitment was compatible with the newly elected Labour Government's commitment to the principle of social inclusion, articulated three months earlier in the White Paper, Excellence in Schools (Department for Education and Employment, 1997). The subsequent Green Paper, Teachers: meeting the challenge of change (Department for Education and Employment, 1998), declared that 'Teaching must attract recruits from every section of society, bring strengths and qualities which ensure that teaching is a vibrant and diverse profession'. The paper went on to announce that the TTA would be asking all training providers 'to set targets for the number of ethnic minority trainees to whom they offer places' (Department for Education and Employment, 1998, p. 46).

Osler (1997), Jones et al (1997) and Siraj-Blatchford (1991) provide invaluable insights into the careers of minority ethnic teachers and their experiences during training. But relatively little has been written about teacher trainers and the issue of ethnicity, or about the strategies deployed in the recruitment and retention of minority ethnic student teachers. The research reported in this article is one strand of an ongoing investigation (begun in 1998) into the motivations and experiences of minority ethnic students from the start of their initial teacher training on Postgraduate Certificate in Education (PGCE) courses through to their first teaching posts. The research investigates the practices of a group of teacher training institutions that have been particularly successful in recruiting minority ethnic students.

Briefly, the first stage of the project involved a postal survey of all those identifying their origins in ethnic minority groups on their Graduate Teacher Training Registry (GTTR) application forms for the PGCE. The second strand of the project, which is the one reported in this article, involved interviews with admissions tutors, course directors and other senior staff at teacher training institutions. A third strand involved interviewing students about their experiences towards the end of their training course. Finally, a postal survey and follow-up interviews were carried out during the first year of full-time teaching.

Of course, the authors of this article have long been aware of the methodological difficulties associated with this kind of research and with the use of conventional ethnic group categorisation (see for example, Demaine, 
1989; Mason, 1990; Bird, 1996). In order to proceed in these early stages of the research we had to make use of 'official' categories. On balance, we consider the research worthwhile despite the limitations.

\section{The Scope of the Research}

The role of 'gatekeepers' is regarded as significant to recruitment to many occupations, and teaching is no exception, although it must be borne in mind that there are strict requirements laid-down by the TTA which admissions tutors in teacher training institutions are not at liberty to ignore. Rather than concerning ourselves with these more or less 'fixed' requirements, our research focused on 'positive' features that admissions tutors might regard as 'good practice' in encouraging recruitment. We followed this line of enquiry in the hope of making a positive contribution to minority ethnic recruitment to teaching. To this end, a series of interviews (with individuals and groups) was undertaken with admissions tutors, course directors and other teacher training staff in 15 English universities and an institution providing School Centred Initial Teacher Training (SCITT).

We provided written details of the scope and purposes of our research prior to the interviews and we gave formal assurances that appropriate steps would be taken to maintain both individual and institutional anonymity. A list of questions, providing a basis for discussion, was sent in advance of the interviews. The following questions were explored: what do you perceive to be the major constraints upon ethnic minority recruitment to, and completion of, PGCEs?; to what extent do your admissions and selection procedures take account of ethnicity?; what special steps, if any, does your institution take to attract ethnic minority teacher-trainees?; to what extent do issues relating to ethnicity feature in your staff training schemes and mentor development programmes?; what strategies do you employ to support ethnic minority students during training?; how are the data supplied by the GTTR utilised by your institution? The interviews were conducted between July and December 1998.

The first analysis of the data was carried out by two members of the research team. A coding frame was devised on the basis of participants' responses to the core questions in the interview schedule described above. The frame allowed us to compare and contrast institutional differences across the former 'binary divide' (i.e. between pre- and post-1992 universities) and also to explore the impact of geographical variations on policy and practice. The results were then compared with independent assessments made by other members of the research team. In adopting this strategy we were cognisant of criticisms that have been made about the reliability of qualitative work (Foster et al, 1996; Tooley \& Darby, 1998). The use of multiple research methods (quantitative and qualitative) enabled us to provide a more comprehensive analysis. Course documentation, prospectuses and other promotional materials, together with evidence from other strands in the 
research (e.g. from our student survey), were utilised for purposes of triangulation.

In addition to the SCITT, our research focused on seven 'old' universities and eight 'new'; the latter having been polytechnics prior to the abolition of the binary divide in Britain in 1992. The significance, for our study, of the distinction between the old and the new lies in the observations made in the Dearing Report (1997) and other commentators (Modood \& Shiner, 1994) that the new universities often have better track-records in widening participation and promoting access. Because of our concern to identify good practice, the investigation focused on institutions with relatively high levels of minority ethnic recruitment. Indeed, over $50 \%$ of the minority ethnic trainees accepted for the PGCE in 1996 (Graduate Teacher Training Registry, 1997) were located in the institutions in our study.

We were aware of the geographical variations in minority ethnic participation in initial teacher training, and in particular the regional concentration in London and south-east England, the Midlands and certain parts of northern England. Two of the institutions in our study were located in northern England, three in the Midlands, four in south-east England and seven in the London area.

\section{The Evidence of the Gatekeepers}

The interviews revealed differences between institutions in the measure taken to attract ethnic minority students (see Table I). Whilst seven of the universities in our research (which it should be remembered had been drawn specifically from institutions that had been successful, historically, in recruiting ethnic minorities) took no special steps to attract ethnic minority trainees, five institutions used targeted advertising in specialist minority press and other media. The use of 'taster' courses was more common among the new universities.

\begin{tabular}{|c|c|c|c|c|}
\hline & $\begin{array}{c}\text { Pre-1992 } \\
\text { Universities } \\
\text { No. of } \\
\text { Mentions }\end{array}$ & $\begin{array}{c}\text { Post-1992 } \\
\text { Universities } \\
\text { No. of } \\
\text { Mentions }\end{array}$ & $\begin{array}{c}\text { SCITT } \\
\text { No. of } \\
\text { Mentions }\end{array}$ & Total \\
\hline No special steps taken & 4 & 3 & 0 & 7 \\
\hline $\begin{array}{l}\text { General advertising (e.g. Website, } \\
\text { local radio, newspapers) }\end{array}$ & 2 & 4 & 0 & 6 \\
\hline $\begin{array}{l}\text { Targeted advertising in minority } \\
\text { media }\end{array}$ & 2 & 2 & 1 & 5 \\
\hline Taster courses & 1 & 3 & 1 & 5 \\
\hline Tapping the local 'grapevine' & 3 & 1 & 1 & 5 \\
\hline $\begin{array}{l}\text { Other (e.g. minority recruitment } \\
\text { targets) }\end{array}$ & 1 & 3 & 1 & 5 \\
\hline
\end{tabular}

Table I. Steps taken to attract ethnic minority trainees. 
The variation in recruitment practice was consistent with the long-standing difference between the new and old sectors noted by Coffield \& Vignoles (1997). In their paper on access, prepared for the Dearing Inquiry, the post1992 universities have tended to promote equal opportunities in their public image and they pursue strategies directed towards specific groups. Whilst the institutions in our sample did not experience difficulty in attracting applications from minority ethnic students, there was geographical variation as well as variation between the ethic groups attracted to particular institutions.

Admissions tutors said that their location, closeness to concentrations of minority ethnic populations, and their reputation were the main factors accounting for their relative success. The PGCE course director at one old university said, 'I think ethnic minority students are attracted to this institution in many ways. Not only by the university and the campus and the kind of reputation that the university has got but also by the range of (teaching practice) schools that we work with that have a multi-ethnic, multicultural background. Many students come to us because they feel that their experience of teacher training will be enriched by working in the kind of schools that we work with.' The course director at another old university made a similar point. 'We are definitely not a local provider, I mean it's less than $30 \%$ of our students who go on into local schools, but people do choose to come here because of the multi-cultural nature of the area.'

Our earlier postal survey had indicated that proximity to place of residence is often a critical factor for many minority ethnic student teachers, particularly mature students with family commitments, and this was confirmed by the interviews. The following response from a tutor at the SCITT makes the point. 'We have older people - not as old as me! - but older people with families, married ladies with families for whom the distance is an accessible distance. The schools are near their homes, this [SCITT] operates near their homes, so that's one of the attractive things. We have got quite a few married ladies [who] need to think about home life and accessibility. And perhaps, if the course was somewhere else, they may not have been as easily accessible.'

An emphasis on establishing and maintaining links with the local community was a common feature in the approach to recruitment taken by most of the institutions in our study. This community orientation was not directed only at ethnic minorities but was part of a broader recruitment strategy. Location in a large, multi-ethnic conurbation was generally regarded as a 'selling point'. The new universities in our study tended to project themselves as local providers with a commitment to equal opportunities and multiculturalism. One new university Head of Department told us that 'the whole University is very strongly focused on its local community, its regional identity and it's well renowned for its commitment to increasing access to higher education. It was one of the first institutions to start Access courses in 
order to try and increase the representation of groups historically underrepresented in higher education - and that certainly included ethnic minority groups. The School of Education, here, has really taken on the University vision and applied it in the context of teacher education and professional development. And so our commitment is to serving the educational needs of the local community. It doesn't mean we're introspective. We have international and national links as well, but we're very keen to work effectively in this urban context and we are keen to recruit students from within the community.' And it is worth re-emphasising, here, that this sense of commitment to the locality did not result in a parochial outlook. Indeed, the same institution also targeted international language students (a fact readily apparent in its course publicity materials) and attracted a significant number of students from abroad.

Whilst the new universities had a more explicit emphasis on local recruitment, this is not to say that the issue was unimportant to the old universities in our sample. Explaining buoyant levels of minority ethnic enrolment, one admissions tutor at an old university told us that 'the most common reason is the content of our course - the vast majority of them said it was the form and structure of our course that attracted them. The second reason was to be near home. But thirdly, because they wanted to be in this city. Over half of them were recommended by a friend.'

Institutions on both sides of the former binary divide and the SCITT in our study deployed a wide variety of recruitment strategies to attract applications from minority ethnic communities. Examples included targeted advertising in the minority ethnic press (for example, The Voice, The Asian Times and other similar local publications); liaising with community organisations; and offering taster courses for minority ethnic students and other under-represented groups (males, for example). Other approaches included advertising on the World Wide Web and the use of local 'Black' music stations to promote courses. In their various advertisements, brochures and prospectuses many institutions featured multicultural representations and emphasised their commitment to minority ethnic recruitment. One of our respondents, a tutor at a new university, reported that 'we started a programme that involves support from the TTA for taster courses for people from ethnic minority backgrounds. These are TTA funded in conjunction with two LEAs. We have two programmes this year specifically for ethnic minorities.' The Secondary course director at our SCITT reported that 'we run what are called taster courses funded by the TTA and these are specifically designed - in most cases - to attract ethnic minority candidates. They have been successful in the sense that we've been oversubscribed. These are two-day courses, where they go into schools and they have an opportunity to discuss what it means to be a teacher with other teachers, both here and in the school.' The Primary Course director added, 'I think because we have had ethnic minority students in the past there is a grapevine. 
There are quite a few that come to us because ethnic minority students have had a successful time and have got jobs, I think that's one thing.'

Other respondents also stressed the significance of the 'grapevine' and personal recommendation in minority ethnic recruitment. For example, the course director at one of our new universities accounted for her own institution's success in attracting applicants saying that 'word is out in the community that we run a very successful course with a high percentage of ethnic minorities working in schools with ethnic minority children. Because somebody has actually been here and has family or extended family at university, the word seems to get around. I think, that's why we've been successful.' The Secondary Course director at an old university concurred with this view, saying that although her institution had made some use of targeted advertising, it was likely that personal recommendation was a more important influence upon its relatively high levels of minority enrolment. "We advertise - when we've got the money - in ethnic minority newspapers. But the impact of that must be pretty marginal. I assume it must be word of mouth.'

\section{Perceived Constraints on Recruitment}

A TTA recruitment drive, which has included a television, cinema and poster campaign using the theme that No One Forgets a Good Teacher was running concurrently with our research. We did not seek admissions tutors' views on the campaign but it was raised by them on several occasions in response to our more general question, 'Is there anything you would like us to pass on to the TTA about how they could improve ethnic minority recruitment into teaching?' The admissions tutor at one of the new universities said, 'I genuinely couldn't because we've been striving for many years to maximise the numbers. But I don't think very much of the TTA's current series of advertisements - No One Forgets a Good Teacher. That garbage would not attract me into the teaching profession.' And the Secondary course director at an old university said that 'with teacher recruitment generally, there is conflict between the image of the advertising campaign and the other messages from officialdom. For example, the constant derision, and complaints about the standard of teaching - it needs to be more consistent. Don't have Chris Woodhead (Her Majesty's Chief Inspector of Schools) shooting his mouth off. Students are very conscious of the adverse, negative stuff - not the advertising campaign. It needs to focus on the image; teaching needs to be seen as a more professional occupation.'

Our earlier postal survey had indicated that admissions tutors' attitude during early contacts, and at the interview, were influential in students' eventual decisions about training at a particular institutions. The first direct experience that an applicant had of the institution was very important. Twelve institutions reported that they took 'no special steps' to vary their admissions or selection procedures to take account of ethnicity and were 
often at pains to emphasise that every case was treated on its merits. In those institutions where tutors said they did take special measures when interviewing minority ethnic applicants there was, nevertheless, a reluctance to deploy overtly different criteria, or to vary procedures. Respondents were often guarded and sometimes gave ambivalent accounts of their practices.

One course director in an institution that endeavoured to interview all minority ethnic applicants insisted that there was 'no dilution of quality' as a result of what was described abstractly as 'affirmative action measures'. A tutor at another old university alluded to the controversy surrounding such measures: 'positive discrimination within the existing rules? I think that positive discrimination is an issue, and I think that it's a difficult issue to discuss as a staff.' At the same time, the Primary course director at a new university said, "We actively seek to offer interviews to any ethnic minority students who apply, and to any men. We offer them the opportunity of an interview but do not lower the standards that they have got to achieve.' Another institution offered advisory interviews for all prospective minority ethnic applicants. They said that potential trainees with 'lower degree classifications would be welcomed' on the basis that, in the words of a Primary course director at an old university, 'the class of degree actually bears no resemblance to what that person is going to end up like as a teacher'. However, the extent to which institutions can continue to operate this kind of flexibility is circumscribed by the stringent course entry requirements laid down by the Department for Education and Employment (DfEE) and TTA, now reinforced by the publication of institutional Performance Profiles (see Teacher Training Agency, 1998). Our respondents said that they thought that the cumulative effect of externally imposed requirements was to leave institutions with very little latitude. The concern for standards, which is shared by all, appears to be increasingly translated into a uniformity of practice that might deny opportunities to respond specifically to cultural and ethnic diversity.

The admissions tutors at many of the institutions in our study said that they wanted to offer all minority ethnic applicants an interview but that this was not straightforward because the GTTR does not provide the institutions with advance information about a candidate's ethnicity. A Primary Course admissions tutor at a new university, clearly frustrated by the lack of information, remarked 'we can't actually identify them (minority applicants) because the GTTR takes the ethnic monitoring bit off the form before we get it. But as I said to you earlier, you can guess possibly by looking at their names or place of birth. Whilst we can't lower the standards for the candidates we choose even for interview, we would look favourably at any ethnic minority students, and any men.' Details of candidates' ethnicity are withheld on the grounds that decisions could be negatively influenced by such information. At the time of writing, this data is sent to institutions only after the students have started their courses. 
Some institutions have their own databases and monitoring systems in place; these institutions were amongst the most critical of the data provided (and withheld) by GTTR. A question about use of GTTR data elicited the following response: "Used" might be putting it a bit strongly! It's kept a careful eye on. We keep an eye on the proportions of applicants interviewed, given places, etc. It's hard to keep track using the GTTR data because it's retrospective.' One new university Head of Department said, 'We make very little use of GTTR data. We generate our own data, which is at least as sophisticated and more detailed.'

Despite the reported shortcomings of the GTTR data, five institutions made use of them for post hoc monitoring of their intakes on a year-by-year basis, and also as an aid to tracking students' progress during training. One old university tutor reported using these data as one of a series of indicators in its annual quality assurance review. But we found a small number of institutions where the senior staff were unaware even of the existence of the data, and others where no use at all was made of them. An admissions tutor in a new university when asked how GTTR data were used said, 'I don't know who gets it in the institution, or even if anybody even looks at it. No I can't answer that question; I don't know who would be able to answer that one.'

\begin{tabular}{lcccc}
\hline & $\begin{array}{c}\text { Pre-1992 } \\
\text { Universities } \\
\text { No. of } \\
\text { Mentions }\end{array}$ & $\begin{array}{c}\text { Post-1992 } \\
\text { Universities } \\
\text { No. of } \\
\text { Mentions }\end{array}$ & $\begin{array}{c}\text { SCITT } \\
\text { No. of } \\
\text { Mentions }\end{array}$ & Total \\
\hline $\begin{array}{l}\text { Low status of teaching } \\
\text { Financial hardship while }\end{array}$ & 3 & 2 & 0 & 5 \\
training & 3 & 1 & 1 & 5 \\
$\begin{array}{l}\text { Teachers' pay and } \\
\text { conditions }\end{array}$ & 1 & 2 & 1 & 4 \\
$\begin{array}{l}\text { TTA standards/entry } \\
\text { requirements }\end{array}$ & 2 & 2 & 0 & 4 \\
$\begin{array}{l}\text { Domestic responsibilities } \\
\text { International qualifications }\end{array}$ & 0 & 3 & 0 & 3 \\
not recognised & 0 & 2 & 1 & 3 \\
$\begin{array}{l}\text { Parental pressures } \\
\text { Racism in schools }\end{array}$ & 1 & 1 & 0 & 2 \\
$\begin{array}{l}\text { Other (e.g. 'There are no } \\
\text { constraints') }\end{array}$ & 0 & 1 & 0 & 1 \\
\hline
\end{tabular}

Table II. Perceived contraints on ethnic minority recruitment to PGCE courses.

Our postal survey had revealed concern about morale within the teaching profession, the pay and conditions of teachers and the high political profile of education. Admissions tutors articulated similar concerns (see Table II) when discussing their perceptions of the constraints on minority ethnic 
recruitment to PGCE courses but our respondents suggested that this factor had salience for all candidates irrespective of background. However, one tutor said that she thought that 'students from ethnic minority backgrounds who have higher degrees go elsewhere, they don't go into teaching, that's the problem'. And another tutor said, 'this may be slightly anecdotal evidence but I've heard from certain students that within the Asian and the African Caribbean community, images of teaching may be slightly negative'. Another admissions tutor said, 'the Asian community are often looking for their young people who do well at school - to become doctors, lawyers, accountants, all things with high status and good money; and teaching is not seen as having high status or good money. Young people of Asian origin, and students actually on our course have told me that.'

On several occasions, admissions tutors indicated that they thought that course entry requirements for the PGCE served to prevent some ethnic minority applicants from gaining a place. As we have already seen, some course-providers felt that the current entry requirements are inflexible and allowed few opportunities for discretion. In particular, non-UK qualifications were not always recognised. This is a problem where students start their education in one country and continue it in another. Our earlier survey showed that graduates with non-UK qualifications represent an important source of minority ethnic recruitment to PGCE courses. Several institutions reported that a more flexible policy would have enabled them to increase their minority ethnic recruitment. The introduction of Performance Profiles, which include quantitative data on students' prior academic attainments both at school and degree levels, could make admissions tutors reluctant to admit students whose qualifications cannot readily be mapped onto the specifications for the Profiles. Crucially, any degree obtained from an institution outside the UK is recorded in the Profiles as a 'Pass' degree, regardless of the actual achievement of the student concerned (Teacher Training Agency, 1998).

Assessment of the impact of Performance Profiles was outside the immediate scope of our study, but admissions tutors' concerns about meeting prescribed entry-standards was evident during our interviewing; this was not confined to recruitment of international students. The following comment, from a senior member of staff at a new university is characteristic. Now that we have Performance Profiles ... they will demonstrate publicly that institutions such as ours have amongst the lowest ' $A$ ' level entry grades and also have the highest proportion of minority ethnic students. The association in the public mind, unfortunately, is not going to be very positive. The pressure, indirectly perhaps, will be to change our admission procedures to try to recruit students who have better ' $A$ ' level points'. This suggests a possible limiting factor to the TTA's efforts to increase minority ethnic recruitment into the teaching profession. There is a body of evidence that shows that the overall attainment levels of pupils from African Caribbean and Bangladeshi backgrounds, for example, tend to be lower than those of other 
ethnic groups (Gillborn \& Gipps, 1996). The TTA policy of driving up the average ' $A$ ' level entry score could press institutions to exclude the very same groups of students from disadvantaged backgrounds that the HEFCE is encouraging universities to accept through its Widening Access Initiative (Higher Education Funding Council for England, 1999).

The issue of qualifications is a greater barrier to recruitment of minority ethnic students to the old universities, which are more likely to be oversubscribed, by well-qualified students, especially in the arts and humanities. The older universities are often able to use high level of entry qualification as a simple and transparent means of selection. As one Secondary course director in an old university put it rather succinctly: 'We are traditional in as much as we say, "You come to us with your degree and we'll decide whether we want to take you or not".' A tutor in another old university said: 'we don't discriminate in any nice or bad sense as far as we know against any particular group of students. The arguments or discussions we have (between ourselves) at the end of our selection interviews are about whether students would be able to survive in an inner-city classroom. We look carefully at those who have been very quiet at interview; who haven't been able to express themselves and don't seem to be very sure of themselves. We certainly don't operate any positive discrimination in any overt way.' An admissions tutor in a new university said that any such measures, if adopted, 'could be a breach of the university's equal opportunities policy and possibly also be in violation of anti-discrimination legislation'. At one of the new universities that is successful in attracting students from Asian backgrounds to its Maths PGCE course, the Secondary Course leader noted that, 'our Maths PGCE recruits a large number of male Asian students. However, we are not taking note of ethnicity when selecting for interview or when we interview. We are just simply noting general qualities, you know, communication skills and all that sort of thing.'

\section{Staying on Course or Dropping Out}

Admissions tutors were divided over their assessment of the factors affecting the retention of ethnic minority trainees on the course (see Table III). Given the proportion of mature trainees among the ethnic minority entrants to PGCE courses, the issue of financial hardship and domestic responsibilities were of particular significance. This had already been apparent from responses to our earlier postal questionnaire. Financial hardship impacts in at least two ways. Some students find that they are unable to complete their course because of lack of funds, while others prejudice their chances of successful completion by taking on part-time jobs to supplement their income. A tutor in an old university said, 'I'm doing some exit interviews at the moment with those who successfully completed the course and I've discovered that a large numbers of them were, in fact, working throughout. 
They will only tell me now, of course, because they were not supposed to be working.'

Our postal survey had highlighted concerns about students encountering racism in schools. In particular, respondents said they were concerned that they might experience isolation in staff rooms, be 'coldshouldered' by teaching staff, and be confronted by racist attitudes among some pupils. Such concerns have been noted in earlier studies including those by Osler (1997), Jones et al (1997) and Siraj-Blatchford (1991). Osler's interviews with sixth-form students revealed that Black and Asian teachers were perceived as being given 'a harder time' than their White counterparts. The ethnic minority trainee teachers in her study expressed anxieties about placements in schools in areas with racist activity. The kinds of question raised included whether 'a White tutor could understand their experiences' of racism (Osler, 1997, p. 179). Osler's study suggests that ethnic minority trainees may be subjected to a variety of additional pressures during their teaching practice. This finding is echoed by Jones et al (1997) and it suggests that pressure may be less pronounced in multi-ethnic schools where staff tend to be more sensitive to the needs and concerns of minority ethnic trainees.

\begin{tabular}{lcccc}
\hline & $\begin{array}{c}\text { Pre-1992 } \\
\text { Universities } \\
\text { No. of } \\
\text { Mentions }\end{array}$ & $\begin{array}{c}\text { Post-1992 } \\
\text { Universities } \\
\text { No. of } \\
\text { Mentions }\end{array}$ & $\begin{array}{c}\text { SCITT } \\
\text { No. of } \\
\text { Mentions }\end{array}$ & Total \\
\hline $\begin{array}{l}\text { Financial hardship while } \\
\text { training }\end{array}$ & 3 & 0 & 0 & 3 \\
$\begin{array}{l}\text { Domestic responsibilities } \\
\text { Language difficulties }\end{array}$ & 2 & 1 & 0 & 3 \\
$\begin{array}{l}\text { TTA Standards } \\
\text { Racism in schools }\end{array}$ & 1 & 2 & 0 & 2 \\
$\begin{array}{l}\text { Racism on campus } \\
\text { Intensive nature of PGCE }\end{array}$ & 0 & 1 & 0 & 2 \\
$\begin{array}{l}\text { course } \\
\text { Level of support during }\end{array}$ & 0 & 1 & 0 & 2 \\
$\begin{array}{l}\text { school placement } \\
\text { Other (e.g. not suited to } \\
\text { teaching) }\end{array}$ & 0 & 0 & 0 & 1 \\
\hline
\end{tabular}

Table III. Perceived constraints on ethnic minority completion of PGCE courses.

Although PGCE staff in only a handful of institutions saw explicit racism as a major constraint upon minority ethnic retention they certainly did not convey the impression that they were blasé about the issue. As one Secondary Course director at a new university said, 'it's much easier to be a white, freewheeling male of 21 . That's the easiest thing to be.' An admissions tutor at another new university said that 'in some of the schools where there aren't any black teachers there is an undercurrent of racism in the staff-room and 
from the parents'. Another tutor referred to a student who had 'walked into the classroom and the children had said, 'Oh, here comes a Paki teacher". But the student didn't tell me about that until she left the school'.

\section{Supporting Support Ethnic Minority Students during Training}

The staff in university departments of education expressed concern about placing trainees in environments where the level of racist activity was perceived to be high. But they were also anxious not to appear to be 'labelling' particular schools or appearing to treat minority ethnic trainees differently from their white peers. An admissions tutor at a new university said, 'there are schools where I wouldn't place certain students from ethnic minority backgrounds because of the pressures they might be subjected to. I'm able to skirt around that to some extent. Certainly, there are racist tensions in some areas'. The course director at another new university recalled that 'about five or six years ago in a particular part of the city where there was evidence of high activity amongst right wing racist groups, and I remember an Asian student saying, 'Hang on, I'm sorry I don't think it's a good idea for me to go there".' Another tutor said that 'we think very carefully before we put Black or Asian students in ... we do de-select, that's to say we take students out, put some in, it's a really delicate issue'.

There was a broad consensus amongst those tutors we interviewed that school placement is a sensitive issue which ideally should not be unduly influenced by concerns arising from trainees' ethnicity. Most institutions encouraged their students to gain a broad range of experience in a variety of contexts. They wanted to be supportive while not being over-protective. They were concerned to provide trainees the opportunity to learn from experiences (both positive and negative) while not exposing them to undue risk or pressure. One institution sought to reconcile these competing demands by giving the trainees themselves a large say in their choice of school placement. A tutor in an old university described her approach saying that 'we give a clear indication of the kind of background of the school, its size, what kind of age-groups would be taught, and then we have a 'Post-it' label system so they can stick their names down and they can elect where to go'. If several trainees wanted to attend a particular school and there were not enough places, they would be encouraged to discuss it amongst themselves and come to a collective decision. A similar practice was described by the course director at another old university who said, 'the principle is quite clear. The students select the school they wish to go to based on the information that the schools have provided. They just go through this with their friends. When they go along for their interview that school has been chosen by them, so there is a sort of psychological bonding almost before they get to the school. It hasn't been imposed upon them.'

Many of the tutors we interviewed referred to the significance of peergroup networking and student support-groups. Some of these were formally 
constituted within the university education department whilst others were ad hoc 'self-help' groups organised by the students themselves. A tutor in an old university said that 'once they go onto teaching placements we suggest to every cohort of students that there are opportunities for a ethnic minority support group to be set up, if they want it. Most years, there will be some such group set up, a smallish group. That group has the right to talk to me and to the PGCE sub-committee if there are any issues to bring forward'. A tutor in another old university said 'we make an arrangement - very early in the course - to meet students and talk to them about providing some kind of support forum. We've called it all sorts of things: 'support group', 'discussion group', 'support forum'. We've had lots of words for it. If students want to be a part, they are a part but if they don't, they needn't be. In fact the majority want to be and they appreciate the opportunities to talk to other people during the year.' The course director at the SCITT said 'there is a high population of ethnic minority trainees on the course who group together, and there is a self-support group. You know, I think that's a very positive thing, it provides affirmation, self-esteem, those kind of things.'

As well as encouraging ethnic minority trainees to develop their own peer networks, many teacher trainers recognised that course modules in multicultural and antiracist education offer an additional means of support. In one of the new universities trainees were provided with the opportunity to explore 'issues of identity and ethnicity' during the PGCE course induction week. The merits of this particular initiative were described by the Primary Course director who said that 'almost everyone who's done that course has said what a difference it made to their feeling of being valued. And all kinds of aspects of their experience being, not only talked about, but seen as something valuable and interesting to discuss'. Despite the potential benefits of such initiatives (for all trainees irrespective of ethnicity) there would appear to be relatively few opportunities for work of this kind in the PGCE. Because of the intensive nature of the course, the current priorities of educational policy-makers and the numerous competing demands upon staff time, such work has been largely relegated to the periphery. According to the Primary Course director at one of the new universities 'people are feeling greater and greater pressure with numeracy, literacy and science becoming the big areas. There is lots of pressure and students' own subject competence is becoming a big issue'.

Several respondents described the strategies employed in their institutions to offer specialist support to speakers of English as an Additional Language. However, in one old university which had taken particular steps to monitor the progress of trainees experiencing difficulties in English, the staff reported that such trainees were sometimes reluctant to take up offers of extra tutorial help with their written work. In another old university the Secondary course director pointed to the resource implications of such provision, particularly in institutions which recruited internationally. 'We can provide support for written language skills because the institution as a whole 
has an English Language Unit to service all the overseas students. But they can't provide support in terms of oral and communicative, interactive skills, which really is where the need lies. Some sort of resourcing which would enable us to put courses on either prior to, or towards the beginning of, the PGCE year, together with ongoing support to develop communicative skills. There are resource implications though.'

As we have already seen, tutors often went to considerable lengths to ensure that ethnic minority trainees were adequately supported both in their placement schools and on campus. Some teacher training tutors said that specific account was taken of religious and cultural difference in the allocation of placement schools. For example, a senior member of staff at an old university stressed that every effort was made 'to accommodate student preferences in terms of religious beliefs, dress codes, and other cultural factors'. Despite the efforts of institutions to meet the religious and cultural needs of individual trainees during placement, there could be no guarantee that staff in partnership schools would show the same sensitivity to difference. A senior tutor at an old university said, 'I was just talking with a young Muslim PGCE science student. She says, "There is a problem as soon as I walk into a school. They look at me and they know I'm different, and I'm immediately treated differently." And I didn't know how to respond to her. She feels there's something - perhaps she's just sensitive to the way she's dressed differently to the majority of the people in the school. There was another story, also (involving) a young Muslim. She was allocated to a school in ... She walked into the school and the deputy head, in the middle of the staff room, walked across and said "welcome". And she said, 'Sorry, I don't shake hands with men", and he went white. He was so angry (that) he phoned me up. Now this indicates the mentor training that we still need to do. $\mathrm{He}$ was an experienced deputy head, had lived in this area 20 years, and he made this elementary cultural mistake.'

\begin{tabular}{|c|c|c|c|c|}
\hline & $\begin{array}{c}\text { Pre-1992 } \\
\text { Universities } \\
\text { No. of } \\
\text { Mentions } \\
\end{array}$ & $\begin{array}{l}\text { Post-1992 } \\
\text { Universities } \\
\text { No. of } \\
\text { Mentions } \\
\end{array}$ & $\begin{array}{c}\text { SCITT } \\
\text { No. of } \\
\text { Mentions }\end{array}$ & Total \\
\hline $\begin{array}{l}\text { Monitoring of } \\
\text { partnership schools/ } \\
\text { careful allocation of } \\
\text { placements }\end{array}$ & 6 & 7 & 1 & 14 \\
\hline $\begin{array}{l}\text { Trainee support } \\
\text { groups/peer tutoring }\end{array}$ & 4 & 4 & 1 & 9 \\
\hline $\begin{array}{l}\text { Antiracism/multicultur } \\
\text { alism course inputs }\end{array}$ & 3 & 4 & 0 & 7 \\
\hline Language support & 2 & 2 & 0 & 4 \\
\hline $\begin{array}{l}\text { Specific steps taken to } \\
\text { meet minority } \\
\text { trainees' cultural }\end{array}$ & 1 & 2 & 0 & 3 \\
\hline
\end{tabular}


Table IV. Strategies employed to support ethnic minority students during training.

At this stage of our research we are unable to say how frequently minority trainees experienced similar incidents during their school placement but a secondary course director at an old university said that in surveys carried out in his institution, reported incidents were 'very, very small indeed'. The same respondent also stated that where such incidents were brought to the attention of university staff, they were dealt with in a prompt manner. For instance, when a student had complained about racist graffiti in one of the lavatories on campus it was 'dealt with within a week. It was taken off the wall, it was painted over, and to me that was an adequate response to an issue that he or she had raised.' Whilst it is a relatively straightforward task to respond robustly to blatant racism, arguably, other more insidious manifestations, such as the 'elementary cultural mistake' referred to above, may be far harder to monitor and challenge. The implications for stafftraining and mentor development would seem to be self-evident.

Equal opportunities issues, including those relating to ethnicity, did not appear to figure prominently in mentor training and staff-development programmes at the institutions in our study. Nevertheless, our respondents did not present themselves as at all blasé about equal opportunities the matters. On the contrary, many had a longstanding and active commitment to multiculturalism and antiracism. However, a number took the view that 'curriculum overload' on the PGCE and the changing priorities of educational policy-makers had led to the marginalisation of such issues. As one Secondary course director said 'we had a staff development session that focused on equal opportunities and, as a consequence of that, we've got a departmental working party. We used to do more, but everyone is now running to keep up with ICT (and) the English, Maths and Science curriculum. The TTA agenda has crowded out at lot of other issues.' Mentor training programmes were similarly circumscribed according to the Head of Department at a new university who said that these 'sessions tend to be tightly focused and 'instrumental' in their concerns'. But despite the constraints, staff in several universities reported that they had taken steps to ensure that equal opportunities were addressed in their mentor training programmes.

\section{Conclusions}

In this article we have reported some of the findings from our research at 16 English initial teacher-training institutions. This work builds on our earlier postal survey of ethnic minority entrants to the PGCE in 1997-98 (see Carrington et al, 1999a). The article has focused on the work of admissions 
tutors and other key staff at institutions with a relatively buoyant level of minority ethnic recruitment across different parts of the country. The institutions in our research were all located in urban areas with substantial minority ethnic populations. In addition to recruitment practices, we have described some of the strategies employed to support postgraduates during their teacher training courses.

A variety of strategies were employed by teacher training institutions to attract minority ethnic trainees. Their prospectuses, brochures and other promotional materials were found to underline their commitment to cultural pluralism and social inclusion. While some institutions made use of targeted advertising in the ethnic minority press, others sought to promote their teacher training courses via the World Wide Web, local Black music stations or community organisations. A number of institutions offered prospective minority applicants 'taster' courses or advisory interviews, or were proactive in cultivating links with their local communities. Although the significance of the 'grapevine' and personal recommendations in ethnic minority recruitment was recognised by institutions on both sides of the former binary divide, the 'new' universities and the SCITT seemed to place greater emphasis on local recruitment than the old universities. Although seven of the universities in our study (four old and three new) took no 'special steps' to attract ethnic minority trainees, admissions tutors and other staff did not convey the impression that they were complacent about ethnic minority recruitment.

The staff interviewed recognised that the location of an institution and its academic status were important reasons for success in recruiting ethnic minority trainees. This corresponded with the findings of our earlier postal survey. Although some institutions took special measures in relation to the interviewing of ethnic minority applicants, in general terms, admissions tutors were reluctant to take explicitly 'affirmative action' that might be construed as leading to 'a dilution of quality'. Nonetheless, admissions tutors recognised the need to achieve a better balance in their intakes but complained that the data supplied by the GTTR were, at best, of limited value for this purpose.

A number of admissions tutors said that they felt that the current entry requirements for the PGCE allowed few opportunities for discretion, either in relation to UK applicants or applicants from overseas. In particular, they would have welcomed a more flexible institutional policy with regard to nonUK qualifications. In addition, some interviewees thought that the TTA requirements relating to proficiency in spoken English could serve to deter some international students from applying to the PGCE. Although admissions tutors were divided in their views about the constraints upon ethnic minority recruitment, a number voiced concern about the public image of teaching that was seen to have an adverse impact on all potential entrants to the PGCE, irrespective of ethnicity. With the relatively large proportion of mature trainees among the ethnic minority entrants to PGCE, 
financial hardship during training was also seen as an additional constraint on ethnic minority recruitment. This factor was also perceived to be a barrier to retention.

Whilst racism in schools was not perceived as a particular barrier to ethnic minority recruitment or retention, tutors were concerned to avoid placing Black and Asian trainees in schools where levels of racial harassment were known to be high. Teacher training staff faced a number of dilemmas when allocating ethnic minority trainees to their placement schools. They were concerned to be supportive but not to cosset. They were conscious of the dangers of labelling schools, and they were concerned to be seen by all trainees as acting in a fair and even-handed manner. In some cases tutors reconcile these competing demands by involving the trainees themselves in decisions relating to the allocation of school placements.

A variety of strategies were employed by universities to support ethnic minority trainees both on campus and during school placement (see Table IV). Amongst other things, some staff underlined the important role played by trainee self-support groups and they drew attention to the provision of multicultural and antiracist education, and to extra-curricular provision of English as an Additional Language. The question of financial support for mature entrants to the PGCE was a matter for concern. Staff said that unless specific measures were adopted to meet their specific needs, the current drive to increase ethnic minority recruitment could founder. Many Black and Asian prospective teachers are 'career changers', who may well balk at the prospect of a significant drop in income during teacher training. In view of the evident tendency for ethnic minority entrants to opt for PGCE places in institutions close to their homes, admissions tutors said that initiatives to extend access in multi-ethnic localities should be encouraged. An expansion of PGCE provision in these areas may be required, coupled with enhanced support for teacher training providers to take a more proactive stance in local recruitment.

As we indicate in our formal reports to the TTA (Carrington et al, 1999a,b,c and 2000) the existing system of ethnic monitoring needs overhauling. If teacher training institutions are to be encouraged to recruit more ethnic minority trainees, the withholding of GTTR data on the ethnicity of applicants is no longer appropriate. Our research indicates a need for much clearer guidelines for admissions tutors on the issues surrounding the question of 'positive action' and particularly their legal position in this respect.

\section{Acknowledgements}

We would like to thank all of the students and staff whose views we have sought during our research. Thanks also to the Teacher Training Agency for financial support of our research and, in particular, to Jane Benham, Head of Teacher Supply and Recruitment at the time of this research. The views and 
interpretations in this article are ours and are not those of the TTA or any other agency. A version of this aspect of our research will be published in a new book, Sociology of Education Today, edited by J. Demaine (2000).

\section{Correspondence}

Dr Jack Demaine, Department of Education, Faculty of Social Sciences and Humanities, Loughborough University, Loughborough LE1 1 3TU, United Kingdom (j.demaine@lboro.ac.uk).

\section{Note}

[1] We have used both 'minority ethnic' and 'ethnic minority' in this article. We have retained the terms used by our respondents and cited in 'official' discourse. For further discussion of changing terminology and categorisation see, for example, Demaine (1989), Mason (1990) and Bird (1996).

\section{References}

Bird, J. (1996) Black Students and Higher Education. Buckingham: Open University Press.

Carrington, B., Bonnett, A., Demaine, J., Nayak, A., Pearce, D., Short, G., Skelton, C., Smith, F. \& Tomlin, R. (1999a) Ethnic Minorities and Teaching: a survey of Postgraduate Certificate in Education students in England and Wales (1998/9). Report Number One to the Teacher Training Agency.

Carrington, B., Nayak, A., Tomlin, R., Bonnett, A., Demaine, J., Short, G. \& Skelton, C. (1999b) Policy and Practice in Sixteen English Initial Teacher Training Institutions. Report Number Two to the Teacher Training Agency.

Carrington, B., Bonnett, A., Demaine, J., Nayak, A., Short, G., Skelton, C., Smith, F. \& Tomlin, R. (1999c) The Perceptions and Experiences of Ethnic Minority PGCE Students. Report Number Three to the Teacher Training Agency.

Carrington, B., Bonnett, A., Demaine, J., Nayak, A., Short, G., Skelton, C., Smith, F. \& Tomlin, R. (2000) Ethnicity and the Professional Socialisation of Teachers. Final Report to the Teacher Training Agency.

Coffield, F. \& Vignoles, A. (1997) Widening Participation in Higher Education by Ethnic Minorities, Women and Alternative Students, in The National Committee of Enquiry into Higher Education, Higher Education in the Learning Society (The Dearing Report). London: Her Majesty's Stationery Office.

Commission for Racial Equality (1986) Black Teachers: the challenge of increasing the supply. London: Commission for Racial Equality.

Commission for Racial Equality (1998) Ethnic Minority School Teachers: a survey in eight local educational authorities. London: Commission for Racial Equality.

Dearing Report (1997) The National Committee of Enquiry into Higher Education, Higher Education in the Learning Society. London: Her Majesty's Stationery Office.

Demaine, J. (1989) Race, Categorisation and Educational Achievement, British fournal of Sociology of Education, 10, pp. 195-214. 
Bruce Carrington et al

Demaine, J. (Ed.) (2000) Sociology of Education Today. London: Macmillan (forthcoming).

Department for Education and Employment (1997) Excellence in Schools. London: Her Majesty's Stationery Office.

Department for Education and Employment (1998) Teachers: meeting the challenge of change. London: Her Majesty's Stationery Office.

Foster, P., Gomm, R. \& Hammersley, M. (1996) Constructing Educational Inequality: an assessment of research on school processes. London: Falmer Press.

Gillborn, D. \& Gipps, C. (1996) Recent Research on the Achievements of Ethnic Minority Pupils. London: Office for Standards in Education (OfSTED).

Graduate Teacher Training Registry (1997) Annual Statistical Report: Autumn 1996 Entry. Cheltenham: Graduate Teacher Training Registry.

Higher Education Funding Council for England (1995) Special Initiative to Encourage Widening Participation of Students from Ethnic Minorities in Teacher Training. Bristol: Higher Education Funding Council for England.

Higher Education Funding Council for England (1999) Widening Participation in Higher Education: request for initial statements of plans and invitation to bid for special funds: 1999-2000 to 2001-02 (Circular 99/33). Bristol: Higher Education Funding Council for England.

Jones, C., Maguire, M. \& Watson, B. (1997) The School Experiences of Some Minority Ethnic Students in London Schools during Initial Teacher Training, Fournal of Education for Teaching, 23, pp. 132-144.

Mason, D. (1990) A Rose by Any Other Name? Categorisation, identity and social science, New Community, 17, 123-133.

Modood, T. \& Shiner, A. (1994) Ethnic Minorities and Higher Education. London: Policy Studies Institute/UCAS.

Osler, A. (1997) The Lives and Careers of Black Teachers: changing identities, changing lives. Buckingham: Open University Press.

Rampton Report (1981) West Indian Children in Our Schools (Interim Report). Cmnd. 8273. London: Her Majesty's Stationery Office.

Siraj-Blatchford, I. (1991) A Study of Black Students Perceptions of Racism in Initial Teacher Education, British Educational Research fournal, 17, pp. 35-50.

Teacher Training Agency (1998) Initial Teacher Training: performance profiles. London: Teacher Training Agency.

Tooley, J. \& Darby, D. (1998) Educational Research: a critique. London: Office for Standards in Education (OfSTED). 